\title{
Alternative Methods to Treat Nausea and Vomiting from Cancer Chemotherapy
}

\author{
Mohammad Ali Sheikhi, ${ }^{1}$ Ahmad Ebadi, \\ Abdolhassan Talaeizadeh, ${ }^{3}$ and Hossein Rahmani ${ }^{4}$ \\ ${ }^{1}$ Department of Cardiac Surgery, Atherosclerosis Research Center Golestan Hospital, Ahvaz Jundishapur University of Medical Sciences, \\ Ahvaz, Iran \\ ${ }^{2}$ Department of Cardiac Anesthesiology, Atherosclerosis Research Center Golestan Hospital and Pain Research Center, \\ Ahvaz Jundishapur University of Medical Sciences, Ahvaz, Iran \\ ${ }^{3}$ Division of Surgery, Emam Hospital, Ahvaz Jundishapur University of Medical Sciences, Ahvaz, Iran \\ ${ }^{4}$ Department of Toxicology, Islamic Azad University, Shahreza Branch and Medical Research Center, \\ Jundishapur Health Development Co., Tehran, Iran
}

Correspondence should be addressed to Hossein Rahmani; r.h1989@yahoo.com

Received 31 May 2015; Revised 9 September 2015; Accepted 10 September 2015

Academic Editor: Vito Lorusso

Copyright (C) 2015 Mohammad Ali Sheikhi et al. This is an open access article distributed under the Creative Commons Attribution License, which permits unrestricted use, distribution, and reproduction in any medium, provided the original work is properly cited.

Chemotherapy Induced Nausea and Vomiting (CINV) is among the most intensive side effects and critical concerns for patients with cancer. Most of these patients experience nausea and vomiting after chemotherapy. Sometimes, this is so annoying that it may prevent them from continuing the therapy. With the recent advances, a variety of therapeutic methods are innovated and applied to control CINV. Among them, the main methods include medicinal therapy, relaxation, and herbal therapy. Yet, using dexamethasone together with massage therapy and ginger is identified as the most effective method.

\section{Introduction}

CINV is the most serious side effect and the main concern for cancer patients. Its prevalence is reported between $54 \%$ and $96 \%$ [1]. This side effect induces physiological and electrolytic dysfunctions, changes in immunity system, nutritional disruption, and even esophageal perforation. Consequently, it affects patients' quality of life and the continuance of treatment [2].

Most patients with cancer experience CINV. The increase of excessive vagus excitation due to sympathetic inhibition is among the most important factors in the manifestation of CINV. Many factors increase the chance of CINV. The most important of them include blood pressure drop, the addition of compounds like vascular contractors, neostigmine, and opioids to anesthetics.

Nausea and vomiting are mostly accompanied with sweating, pale skin, and heart palpitation. If not treated, it results in acute dehydration, the imbalance of liquids and electrolytes, and emotional tensions among patients [3]. Similarly, not controlling nausea and vomiting will result in extravagant costs. Among them, direct and indirect costs can be implied. Direct costs include the increase of hospitalization days as well as the extra costs related to medical and nursing cares. Yet, indirect costs include patients', their family members', and (or) caregivers' income loss or reduction. Recently, various methods are applied to control CINV including medicinal or complementary therapies. The selection and prescription of appropriate therapies, medicinal or nonmedicinal therapies, will considerably improve cancer patients' quality of life and performance. They will have desirable effects on their life [4].

With the recent advances, a variety of therapeutic methods are innovated and applied to control CINV. Hence, the present study reviews the methods of reducing CINV in patients with cancer. 
TABLE 1: The effect of medicinal therapy on the intensity of nausea and vomiting in cancer patients under chemotherapy.

\begin{tabular}{|c|c|c|c|c|c|}
\hline Study & Year & Sample size & Design/population & Method & Outcome \\
\hline $\begin{array}{l}\text { Ekangaki and } \\
\text { Chung [5] }\end{array}$ & 2005 & 450 & $\begin{array}{l}\text { Cancer patients under } \\
\text { chemotherapy in two } \\
\text { various age-gender } \\
\text { groups }\end{array}$ & Case-control & $\begin{array}{l}\text { The application of histamines, phenothiazines, } \\
\text { butyrophenones, and anticholinergics to cope } \\
\text { with CINV in chemotherapy brings about side } \\
\text { effects }\end{array}$ \\
\hline $\begin{array}{l}\text { Sirin and Flynn } \\
\text { [6] }\end{array}$ & 2013 & 52 & $\begin{array}{l}\text { Cancer patients under } \\
\text { chemotherapy in two } \\
\text { various age-gender } \\
\text { groups }\end{array}$ & Case-control & $\begin{array}{l}\text { CINV was reduced by about } \% 13.8 \text { in the group } \\
\text { receiving dimenhydrinate as compared to } \\
\text { placebo }\end{array}$ \\
\hline $\begin{array}{l}\text { Pierce and Lin } \\
\text { [7] }\end{array}$ & 2013 & 85 & $\begin{array}{l}\text { Over } 30 \text {-year-old men } \\
\text { with prostate cancer } \\
\text { under chemotherapy }\end{array}$ & Case-control & $\begin{array}{l}\text { Prescribing dimenhydrinate for men with } \\
\text { prostate cancer under chemotherapy has } \\
\text { reduced their CINV as compared to control } \\
\text { group }\end{array}$ \\
\hline $\begin{array}{l}\text { Sheanakul et al. } \\
\text { [8] }\end{array}$ & 2011 & 30 & $\begin{array}{l}\text { Below } 60 \text {-year-old } \\
\text { cancer patients under } \\
\text { chemotherapy in two } \\
\text { gender groups }\end{array}$ & Case-control & $\begin{array}{l}\text { The continuous injection of midazolam has } \\
\text { reduced pain and CINV in test group as } \\
\text { compared to control group }\end{array}$ \\
\hline Apfel et al. [9] & 2012 & 23 & $\begin{array}{l}15-50 \text { years of age } \\
\text { cancer patients under } \\
\text { chemotherapy in two } \\
\text { gender groups }\end{array}$ & Case-control & $\begin{array}{l}\text { Cinnarizine controls and reduces CINV in } \\
\text { cancer patients under chemotherapy as } \\
\text { compared to placebo group through hindering } \\
\text { histaminic H1 receptor }\end{array}$ \\
\hline $\begin{array}{l}\text { Rosenthal et al. } \\
\text { [10] }\end{array}$ & 2010 & 64 & $\begin{array}{l}\text { Over } 12 \text {-year-old } \\
\text { cancer patients under } \\
\text { chemotherapy in two } \\
\text { various gender groups }\end{array}$ & Clinical trial & $\begin{array}{l}\text { Metoclopramide reduces CINV in cancer } \\
\text { patients under chemotherapy through } \\
\text { enhancing the activity threshold of CTZ } \\
\text { chemical receptors }\end{array}$ \\
\hline $\begin{array}{l}\text { Denehy et al. } \\
\text { [11] }\end{array}$ & 2011 & 85 & $\begin{array}{l}\text { Cancer patients under } \\
\text { chemotherapy in two } \\
\text { various age-gender } \\
\text { groups }\end{array}$ & Case-control & $\begin{array}{l}\text { CINV is less in cancer patients under } \\
\text { chemotherapy receiving metoclopramide as } \\
\text { compared to the group receiving placebo }\end{array}$ \\
\hline
\end{tabular}

\section{Descried}

2.1. The Effect of Medicinal Therapy on the Intensity of Nausea and Vomiting in Cancer Patients under Chemotherapy. Among the medicinal methods for the prevention and treatment of CINV, antihistamines, phenothiazines, butyrophenones, and anticholinergics can be implied. Yet, their application is partially limited due to their side effects [5]. Among the antiemetic drugs available, no single antinauseant is capable of controlling CINV on its own. Some of them can be applied in limited dosages due to their side effects. As a result, researchers seek for more effective compounds with fewer side effects.

Dimenhydrinate, midazolam, and metoclopramide are amongst the main drugs prescribed by physicians for controlling and suppressing CINV in cancer patients under chemotherapy.

Dimenhydrinate is an antihistamine drug. It reduces the activity of labyrinth and CTZ center in medulla by its anticentral-muscarinic effect and, finally, hinders nausea and vomiting. Sirin carried out a study concerning the effect of dimenhydrinate on reducing CINV in cancer patients under chemotherapy. He concluded that CINV decreased about $13.8 \%$ in patients receiving the drug as compared to the group receiving placebo [6]. In another study, it was also shown that prescribing dimenhydrinate for men with prostate cancer under chemotherapy has reduced their CINV as compared to control group [7]. In their study, Sheanakul et al. reported that the permanent injection of midazolam in cancer patients under chemotherapy has reduced pain and CINV in test group as compared to control group [8]. In a study, it was reported that, hindering histaminic $\mathrm{H} 1$ receptor, cinnarizine controls and reduces CINV in cancer patients under chemotherapy as compared to placebo group [9]. In another study, it was reported that metoclopramide reduces CINV in cancer patients under chemotherapy through enhancing the activity threshold of CTZ chemical receptors [10]. In a study by Denehy et al., it was shown that CINV is less in cancer patients under chemotherapy receiving metoclopramide as compared to placebo group [11] (Table 1).

2.2. The Effect of Relaxation Methods on the Intensity of Nausea and Vomiting in Cancer Patients under Chemotherapy. Nowadays, nonmedicinal therapies such as relaxation techniques have been proposed for treating CINV.

Some studies show that relaxation response that emerged from massage is effective in controlling nausea [12].

In a study on breast cancer patients receiving radiation therapy, it was reported that patients cited the reduction of pain, uneasiness, nausea, fatigue, and tension, yet the increase of relaxation response and the vital force after massage [13]. Results of a study showed that supportive, behavioral, cognitive, relaxation, and visualization techniques have reduced cancer patients' postchemotherapy pain yet not nausea [14]. 
TABLE 2: The effect of relaxation methods on the intensity of nausea and vomiting in cancer patients under chemotherapy.

\begin{tabular}{|c|c|c|c|c|c|}
\hline Study & Year & $\begin{array}{c}\text { Sample } \\
\text { size }\end{array}$ & Design/population & Method & Outcome \\
\hline Houston and Scholes [12] & 2004 & 75 & $\begin{array}{l}\text { Cancer patients under } \\
\text { chemotherapy in various } \\
\text { age-gender groups }\end{array}$ & Case-control & $\begin{array}{l}10 \mathrm{~min} \text { feet massage is effective in reducing } \\
\mathrm{CINV}\end{array}$ \\
\hline Lefebvre [13] & 2005 & 120 & $\begin{array}{l}\text { Over } 30 \text {-year-old women with } \\
\text { breast cancer under radiation } \\
\text { therapy }\end{array}$ & Clinical trial & $\begin{array}{l}\text { Massage therapy is effective in reducing } \\
\text { nausea }\end{array}$ \\
\hline Yusrizal et al. [14] & 2006 & 56 & $\begin{array}{l}\text { Cancer patients under } \\
\text { chemotherapy in various } \\
\text { age-gender groups }\end{array}$ & Case-control & $\begin{array}{l}\text { Supportive behavioral, cognitive, relaxation, } \\
\text { and visualization techniques did not affect } \\
\text { CINV }\end{array}$ \\
\hline $\begin{array}{l}\text { Viswanathan and } \\
\text { Eisenberg [15] }\end{array}$ & 2006 & 112 & $\begin{array}{l}\text { Cancer patients with normal } \\
\text { hearing under chemotherapy }\end{array}$ & Case-control & $\begin{array}{l}\text { Instruction of relaxation using audio tape } \\
\text { was effective in reducing the intensity of } \\
\text { delayed nausea and vomiting in patients } \\
\text { with cancer }\end{array}$ \\
\hline Lapoint et al. [16] & 2006 & 44 & $\begin{array}{l}\text { Cancer patients under } \\
\text { chemotherapy in various } \\
\text { age-gender groups }\end{array}$ & Case-control & $\begin{array}{l}\text { Using acupuncture in patients receiving } \\
\text { chemotherapy brings about antinausea } \\
\text { effects. Yet, results were not statistically } \\
\text { significant }\end{array}$ \\
\hline Radtke and Lapoint [17] & 2004 & 15 & $\begin{array}{l}\text { Patients over } 12 \text { years of age } \\
\text { under chemotherapy in two } \\
\text { gender groups }\end{array}$ & Clinical trial & $\begin{array}{l}\text { A combination of music therapy and } \\
\text { visualization was not effective regarding the } \\
\text { reduction of nausea }\end{array}$ \\
\hline Brandt et al. [18] & 2005 & 87 & $\begin{array}{l}\text { Cancer patients under } \\
\text { chemotherapy in various } \\
\text { age-gender groups }\end{array}$ & Case control & $\begin{array}{l}\text { Moderately massaging patients' back } \\
\text { reduced nausea in cancer patients under } \\
\text { chemotherapy }\end{array}$ \\
\hline Hummerston et al. [19] & 2011 & 80 & $\begin{array}{l}\text { Cancer patients under } \\
\text { chemotherapy in various } \\
\text { age-gender groups }\end{array}$ & Case-control & $\begin{array}{l}\text { Ice massage in cancer patients under } \\
\text { chemotherapy decreases the amount of } \\
\text { nausea and vomiting to } 45 \% \text { as compared to } \\
\text { control group }\end{array}$ \\
\hline $\begin{array}{l}\text { Chik and Morrow } \\
{[20]}\end{array}$ & 2013 & 19 & $\begin{array}{l}\text { Patients with gastric cancer } \\
\text { between } 20 \text { and } 40 \text { years of age in } \\
\text { two gender groups }\end{array}$ & Case-control & $\begin{array}{l}\text { Massaging in water is effective in reducing } \\
\text { CINV in patients under chemotherapy }\end{array}$ \\
\hline
\end{tabular}

In a study by Viswanathan and Eisenberg, it was said that $25 \mathrm{~min}$ instruction of relaxation using audio tape was effective in reducing the intensity of delayed nausea and vomiting in patients with cancer [15]. In another study, it was reported that using acupuncture in patients receiving chemotherapy induces antinausea effects. Yet, the results were not statistically significant [16]. Radtke and Lapoint used a combination of music therapy and visualization for reducing anxiety in 15 patients receiving chemotherapy. He found out that anxiety and the intensity of vomiting were significantly reduced. However, no changes were reported regarding the amount of nausea [17]. In a study by Brandt et al., it was reported that moderately massaging patients' back led to relaxation, emotional health, appetite improvement, and nausea reduction in cancer patients receiving chemotherapy [18]. It was shown in a study that ice massage in cancer patients under chemotherapy decreases nausea and vomiting to $45 \%$ as compared to control group [19]. Similarly, Chik and Morrow implied the effect of massage in water on reducing CINV in patients with gastric cancer [20].

Based on these results, nurses can effectively apply massage to alleviate pain, nausea in patients with cancer. Accordingly, patients and their families will be trained in this regard. It is noteworthy that one of the main objectives of nursing cares is to provide patients with relaxation and peace. Researcher nurses recommend the application of complementary methods to reduce patients' nausea (Table 2).

\subsection{The Effect of Adding Medicinal Plants to Conventional} Therapy on the Intensity of Nausea and Vomiting in Cancer Patients under Chemotherapy. The wide use of industrial antivomiting drugs for coping with CINV is accompanied with adverse side effects including extra pyramidal side effects, blood pressure drop, and headache. Hence, there has been an increasing tendency to use herbal plants.

Today, plants have drawn considerable interest in the field of treatment as compared to chemical drugs. It is due to having more advantages yet fewer side effects as well as being more cost-effective. Based on a WHO report, about $80 \%$ of the world population apply herbal compounds now [21].

Few plans have been used for treating nausea and vomiting, especially, in cancer patients receiving chemotherapy. Citrus aurantium, Hypericum perforatum L., Achillea millefolium L., and Zingiber officinale are the only plants that induced successful results; especially, in the same regard. They are also of specific significance for researchers.

Orange blossom (scientific name: Citrus aurantium) was used in traditional medicine for treating many diseases. 
During the recent decade, again, it has been considered in controlling CINV. In a study by Zhou et al., it was reported that the application of this plant extract reduces nausea and vomiting in patients with lung cancer as compared to control [22]. In another study, it was shown that nausea and vomiting were reduced in ovarian cancer women receiving Citrus aurantium capsules [23].

In the recent decade, we have observed interesting studies regarding the effect of Hypericum (scientific name: Hypericum perforatum L.) and Achillea (scientific name: Achillea millefolium L.) on the reduction of CINV. For instance, in their study, Laniyonu et al. stated that Hypericum perforatum $L$. reduces CINV in test group as compared to control group [24]. In another study, it was reported that Achillea millefolium $L$. reduces CINV by about $23 \%$ in test group as compared to control group [25]. In a study, concerning the effect of Citrus aurantium, Hypericum perforatum L., Achillea millefolium L., and Zingiber officinale on reducing $\mathrm{CINV}$ in various age and gender groups, it was shown that Zingiber officinale induces better effect on reducing CINV as compared to other plants mentioned [26].

Zingiber officinale is among the herbal plants effective in treating nausea and vomiting without any side effects. In German pharmacopoeia, it is applied to develop antinausea drugs [27]. The major pharmacological activity of ginger (scientific name: Zingiber officinale) is related to its active components including gingerol and shogaol. These compounds have antivomiting, antifever, anticoughing, antiinflammatory, antipressure, and anticancer effects. They also reduce prostaglandin and alleviate digestive problems. Zingiber officinale derivatives employ their antivomiting effects through several mechanisms. For instance, gingerol and shogaol decrease gastric contractions yet increase digestive (gastrointestinal) tract activity. These compounds also have antiserotonin effect. They have sweeping effects on free radicals inducing nausea [28]. To examine the application of Zingiber officinale for cancer patients, a study was conducted on 50 cancer patients under chemotherapy. The results of this study as "Zingiber officinale: An Anti-Vomiting Factor in Postchemotherapy Nausea and Vomiting" showed that Zingiber officinale was more effective in controlling nausea and vomiting as compared to metoclopramide [29]. There are studies indicating paradoxical results. For instance, in a study concerning the effect of Zingiber officinale on postsurgery nausea and vomiting in 180 women undergoing genital tract laparoscopy, it was shown that this plant has no effect on postsurgery nausea and vomiting. No difference was observed between test and control group [30]. Similarly, a study on 43 cancer patients under chemotherapy aiming to determine the antivomiting effects of Zingiber officinale on CINV showed that Zingiber officinale is effective in reducing CINV in delayed phase [28].

Regarding the fact that the number of studies emphasizing the effectiveness of Zingiber officinale is more than that of the studies rejecting it and concerning study [30] it can be concluded that these results are probably due to the small size of the sample, limited number of participants, and the lack of access to high quality product. This is because the characteristics of the previous studies are so that they can affect their results. In a study, it was implied that $48.3 \%$ in Zingiber officinale group and $66.7 \%$ in placebo group manifested nausea. Hence, the effectiveness of Zingiber officinale is $18.4 \%$ [31]. The results of another study showed that changes in nausea mean scores were higher among all participants in Zingiber officinale group as compared to placebo group. That is, after receiving the diets under study, 28 out of 32 patients in Zingiber officinale group (87.5\%) and 10 out of 35 patients in placebo group (28.2\%) reported nausea improvement [32]. In their study, Levine et al. showed that Zingiber officinale together with protein in the diet reduces delayed nausea and the consumption of antinausea drugs [33]. On the other hand, another study indicates the further effectiveness of Zingiber officinale as compared to dimenhydrinate with fewer side effects [34]. Similarly, Ozgoli et al. emphasized the application of Zingiber officinale as a herbal medication to control CINV in patients receiving chemotherapy [35]. Based on the results of the abovementioned studies, it can be stated that the application of capsules containing Zingiber officinale powder can alleviate CINV without any special side effects. Hence, it is possible to improve patients' condition and reduce chemotherapy-induced side effects by providing instructional plans and equipment regarding how to use these capsules (Table 3).

\section{Conclusion}

Based on the studies discussed in this review, it can be said that among the relaxation methods for alleviating CINV, the massage therapy of various members brings about the best results without any side effects depending on the type of cancer. It has also desirable mental effects on patients' health.

Concerning herbal therapies, it can also be reported that researchers in the field of chemotherapy have given prime significance to Zingiber officinale. This plant induces acceptable effects on the reduction of CINV.

In the end, based on the results of this study, it can be generally concluded that Zingiber officinale (in form of ginger capsule) is the best option among antinausea medications to CINV. Depending on the type of cancer, it is applied due to cost-effectiveness and less side effects as compared to other herbal drugs. During the treatment of CINV, massage therapy is also recommended at certain hours of the day and night due to its desirable effects on reducing patients' nausea and vomiting as well as their mental health.

No studies are available concerning the simultaneous examination of massage therapy, herbal therapy, and dexamethasone therapy regarding the reduction of nausea and vomiting in patients with cancer. Hence, it is recommended that various types of cancers are studied based on abovementioned objective.

In conclusion, herbal and massage therapy is the safety way to treat CINV and it may reduce side effect of toxicity such as liver toxicity. 
TABLE 3: The effect of adding medicinal plants to conventional therapy on the intensity of nausea and vomiting in cancer patients under chemotherapy.

\begin{tabular}{|c|c|c|c|c|c|}
\hline Study & Year & Sample size & Design/population & Method & Outcome \\
\hline Zhou et al. [22] & 2012 & 24 & $\begin{array}{l}\text { Lung cancer patients under } \\
\text { chemotherapy in various } \\
\text { age-gender groups }\end{array}$ & Case-control & $\begin{array}{l}\text { Citrus aurantium extract reduces nausea and } \\
\text { vomiting in patients with lung cancer as } \\
\text { compared to control group }\end{array}$ \\
\hline $\begin{array}{l}\text { Pelletier and Ravi } \\
\text { [23] }\end{array}$ & 2013 & 58 & $\begin{array}{l}\text { Women over } 20 \text { years of age } \\
\text { with ovary cancer receiving } \\
\text { chemotherapy }\end{array}$ & Case-control & $\begin{array}{l}\text { Citrus aurantium capsule reduces nausea and } \\
\text { vomiting in women with ovary cancer receiving } \\
\text { chemotherapy as compared to placebo group }\end{array}$ \\
\hline Laniyonu et al. [24] & 2011 & 42 & $\begin{array}{l}\text { Cancer patients under } \\
\text { chemotherapy in various } \\
\text { age-gender groups }\end{array}$ & Case-control & $\begin{array}{l}\text { Hypericum perforatum } L \text {. reduces nausea and } \\
\text { vomiting in patients with lung cancer as } \\
\text { compared to control group }\end{array}$ \\
\hline Tian et al. [25] & 2012 & 70 & $\begin{array}{l}\text { Patients under } \\
\text { chemotherapy in various } \\
\text { age-gender groups }\end{array}$ & Case-control & $\begin{array}{l}\text { Achillea millefolium L. reduces CINV by about } \\
23 \% \text { in test group as compared to placebo } \\
\text { group }\end{array}$ \\
\hline $\begin{array}{l}\text { Steingraber and } \\
\text { Alrawi [26] }\end{array}$ & 2013 & 96 & $\begin{array}{l}\text { Cancer patients under } \\
\text { chemotherapy in various } \\
\text { age-gender groups }\end{array}$ & Case-control & $\begin{array}{l}\text { Zingiber officinale is more effective on reducing } \\
\text { CINV as compared to Citrus aurantium, } \\
\text { Hypericum perforatum L., and Achillea } \\
\text { millefolium L. }\end{array}$ \\
\hline $\begin{array}{l}\text { Eberhart and } \\
\text { Sripramote [28] }\end{array}$ & 2011 & 43 & $\begin{array}{l}\text { Women with ovary cancer } \\
\text { receiving chemotherapy in } \\
\text { various age groups }\end{array}$ & Case-control & $\begin{array}{l}\text { Zingiber officinale is more effective on reducing } \\
\text { CINV in delayed phase }\end{array}$ \\
\hline Sontakke et al. [29] & 2003 & 50 & $\begin{array}{l}\text { Cancer patients under } \\
\text { chemotherapy in various } \\
\text { age-gender groups }\end{array}$ & Case-control & $\begin{array}{l}\text { Zingiber officinale is more effective on reducing } \\
\text { CINV as compared to metoclopramide }\end{array}$ \\
\hline Eberhart et al. [30] & 2003 & 180 & $\begin{array}{l}\text { Women undergoing genital } \\
\text { tract laparoscopy }\end{array}$ & Clinical trial & $\begin{array}{l}\text { The null effect of Zingiber officinale on nausea } \\
\text { and vomiting }\end{array}$ \\
\hline $\begin{array}{l}\text { Nanthakomon and } \\
\text { Pongrojpaw [31] }\end{array}$ & 2006 & 80 & $\begin{array}{l}\text { Cancer patients under } \\
\text { chemotherapy in various } \\
\text { age-gender groups }\end{array}$ & Case-control & $\begin{array}{l}\text { The effectiveness of Zingiber officinale on } \\
\text { nausea and vomiting was reported }\end{array}$ \\
\hline $\begin{array}{l}\text { Beytz and } \\
\text { Ratehanon [32] }\end{array}$ & 2012 & 67 & $\begin{array}{l}\text { Cancer patients under } \\
\text { chemotherapy in various } \\
\text { age-gender groups }\end{array}$ & Case-control & $\begin{array}{l}\text { Zingiber officinale is more effective on reducing } \\
\text { CINV as compared to placebo }\end{array}$ \\
\hline Levine et al. [33] & 2008 & 73 & $\begin{array}{l}\text { Cancer patients under } \\
\text { chemotherapy in various } \\
\text { age-gender groups }\end{array}$ & Case-control & $\begin{array}{l}\text { Zingiber officinale together with protein in the } \\
\text { diet reduces delayed nausea and the } \\
\text { consumption of antinausea drugs }\end{array}$ \\
\hline $\begin{array}{l}\text { Kasper and Pierce } \\
{[34]}\end{array}$ & 2011 & 52 & $\begin{array}{l}\text { Cancer patients under } \\
\text { chemotherapy in various } \\
\text { ages }\end{array}$ & Case-control & $\begin{array}{l}\text { Further effectiveness of Zingiber officinale as } \\
\text { compared to dimenhydrinate }\end{array}$ \\
\hline Ozgoli et al. [35] & 2009 & 80 & $\begin{array}{l}\text { Cancer patients under } \\
\text { chemotherapy in various } \\
\text { ages }\end{array}$ & Case-control & $\begin{array}{l}\text { Zingiber officinale is emphasized as a herbal } \\
\text { medication for controlling CINV }\end{array}$ \\
\hline
\end{tabular}

\section{Conflict of Interests}

The authors declare that there is no conflict of interests regarding the publication of this paper.

\section{Acknowledgments}

Hereby, the authors sincerely thank all colleagues, friends, and professors for their contributions to the execution of this study.

\section{References}

[1] J. Klein and P. Griffiths, "Acupressure for nausea and vomiting in cancer patients receiving chemotherapy," British Journal of Community Nursing, vol. 9, no. 9, pp. 383-387, 2004.
[2] D. C. Dugdale, "Nasuea and vomiting," Medlineplus, http://nlm .nih.gov/medlineplus/ency/article/003117.htm.

[3] F. Jeriko and S. Madellin, Nursing Care of Children and Adolescents with Cancer, Saunders, Philadelphia, Pa, USA, 6th edition, 2004.

[4] M. Miller and N. Kearney, "Chemotherapy-related nausea and vomiting-past reflections, present practice and future management," European Journal of Cancer Care, vol. 13, no. 1, pp. 71-81, 2004.

[5] F. Ekangaki and R. Chung, "Gastrointestinal pharmacology," in Clinical Pharmacology for Anaesthetists, J. G. Bovill and M. B. Howie, Eds., pp. 16-98, W.B. Saunders Company, London, UK, 1st edition, 2005.

[6] K. Sirin and J. Flynn, "Effect of dimenhydrinate on nausea and vomiting in cancer patients under chemotherapy," European Journal of Cancer Care, vol. 69, no. 6, pp. 81-96, 2013. 
[7] D. Pierce and R. H. Lin, "Effect of dimenhydrinate on nausea and vomiting in prostate cancer patients under chemotherapy," Biological and Pharmaceutical Bulletin, vol. 65, no. 7, pp. 54-73, 2013.

[8] Z. Sheanakul, G. Gaur, and O. Singh, "Midazolam: an effective on nausea and vomiting in cancer patients under chemotherapy," Anesthesia \& Analgesia, vol. 48, no. 5, pp. 63-87, 2011.

[9] F. Apfel, N. Silver, D. Bose, and L. H. Beverly, "Cinnarizine effectively reduces nausea and vomiting in cancer patients," Chang Gung Medical Journal, vol. 43, no. 2, pp. 54-76, 2012.

[10] V. Rosenthal, B. Radtke, M. Jordan, and S. Choararatana, "Effect of metoclopramide on nausea and vomiting in cancer patients under chemotherapy," European Journal of Cancer Care, vol. 42, no. 6, pp. 32-54, 2010.

[11] Y. Denehy, B. F. Ho, D. Liu, and R. Christofi, "Effect of metoclopramide and placebo on nausea and vomiting in cancer patients under chemotherapy," The Journal of International Medical Research, vol. 54, no. 7, pp. 65-87, 2011.

[12] P. Houston and C. Scholes, "Foot massage: a nursing intervention to modify the distressing symptoms of pain and nausea in patients hospitalized with cancer," Cancer Nursing, vol. 54, no. 2, pp. 156-168, 2004.

[13] A. Lefebvre, "Effect of relaxation, imaging on PONVin brass cancer," Cancer Nursing, vol. 13, no. 2, pp. 178-187, 2005.

[14] K. Yusrizal, N. Deuson, and C. Hawks, "Relaxation, imaging and cognitive-treatment. Pain," Chang Gung Medical Journal, vol. 14, no. 7, pp. 65-88, 2006.

[15] M. Viswanathan and Z. Eisenberg, "Relaxation to reduce nausea, vomiting and anxiety induced by chemotherapy in Japanese patients," Cancer Nursing, vol. 54, no. 20, pp. 245-256, 2006.

[16] D. Lapoint, P. Kuhly, and K. Robertson, "Effects of relaxation to reduce PONV induced by chemotherapy," Supportive Cancer Therapy, vol. 14, no. 9, pp. 78-95, 2006.

[17] D. Radtke and T. Lapoint, "Managing the multiple causes of nausea and vomiting in the patient with cancer," Oncology Cancer Nursing, vol. 53, no. 7, pp. 176-188, 2004.

[18] F. Brandt, V. Singh, and Y. Franck, "Effect of managing the multiple cause of PONV in the patient with cancer," Cancer Nursing, vol. 37, no. 8, pp. 54-67, 2005.

[19] P. Hummerston, B. Leclaire, and N. Kocagil, "Effect of ice massage on nausea and vomiting in patients under chemotherapy," Journal of Obstetric, Gynecologic, \& Neonatal Nursing, vol. 73, no. 7, pp. 85-92, 2011.

[20] S. Chik and C. Morrow, "Effect of water massage on nausea and vomiting in patients with cancer under chemotherapy," European Journal of Cancer Care, vol. 46, no. 5, pp. 54-63, 2013.

[21] J. T. Hickok, J. A. Roscoe, G. R. Morrow, and J. L. Ryan, "A phase II/III randomized, placebo-controlled, double-blind clinical trial of ginger (Zingiber officinale) for nausea caused by chemotherapy for cancer: a currently accruing URCC CCOP Cancer Control study," Supportive Cancer Therapy, vol. 4, no. 4, pp. 247-250, 2007.

[22] L. Zhou, T. Perez, and B. Wieland, "Effects of Citrus aurantium flowers aqueous extract on nausea and vomiting in cancer patients under chemotherapy," Hong Kong Medical Journal, vol. 63, no. 6, pp. 12-37, 2012.

[23] V. Pelletier and M. H. Ravi, "The effect of Citrus aurantium flowers extract on intervention on nausea and vomiting," Support Care Cancer, vol. 47, no. 11, pp. 6-143, 2013.

[24] B. Laniyonu, D. Jones, and R. Wong, "Effect of Hypericum pertoratum $\mathrm{L}$ extract on intervention on nausea and vomiting due to chemotherapy in patients cancer," Biological and Pharmaceutical Bulletin, vol. 43, no. 4, pp. 98-119, 2011.

[25] F. Tian, C. H. Lau, Z. Biella, and M. Caran, "The placebo effect and Achilea mille folium L extract on intervention on nausea and vomiting due to chemotherapy in patients cancer," Experimental Physiology, vol. 96, no. 6, pp. 157-169, 2012.

[26] L. Steingraber and R. Alrawi, "Comparison of Citrus aurantium, Hypericu pertoratum, Achillea millefolium $\mathrm{L}$ and ginger extracts on intervention on nausea and vomiting due to chemotherapy in patients with cancer," Cancer Nursing, vol. 54, no. 9, pp. 74-89, 2013.

[27] Z. Petchpaisit, "The Effect of ginger on nausea and vomiting in cancer patients under chemotherapy," Journal of the Medical Association of Thailand, vol. 97, no. 17, pp. 215-226, 2013.

[28] D. Eberhart and L. Sripramote, "Effect of ginger on nausea and vomiting in patients under chemotherapy," Journal of Gynecological Cancer, vol. 42, pp. 1063-1078, 2011.

[29] S. Sontakke, V. Thawani, and M. S. Naik, "Ginger as an antiemetic in nausea and vomiting induced by chemotherapy: a randomized, cross-over, double blind study," Indian Journal of Pharmacology, vol. 35, no. 1, pp. 32-36, 2003.

[30] L. H. J. Eberhart, R. Mayer, O. Betz et al., "Ginger does not prevent postoperative nausea and vomiting after laparoscopic surgery," Anesthesia \& Analgesia, vol. 96, no. 4, pp. 995-998, 2003.

[31] T. Nanthakomon and D. Pongrojpaw, "The efficacy of ginger in prevention of postoperative nausea and vomiting after major gynecologic surgery," Journal of the Medical Association of Thailand, vol. 89, no. 4, pp. 130-136, 2006.

[32] T. Beytz and M. Ratehanon, "Effects of Ginger for nausea and vomiting in cancer patients under chemotherapy," Obstetrics \& Gynecology, vol. 86, no. 8, pp. 147-159, 2012.

[33] M. E. Levine, M. G. Gillis, S. Y. Koch, A. C. Voss, R. M. Stern, and K. L. Koch, "Protein and ginger for the treatment of chemotherapy-induced delayed nausea," Journal of Alternative and Complementary Medicine, vol. 14, no. 5, pp. 545-551, 2008.

[34] C. Kasper and B. Pierce, "A randomized comparison of ginger and dimenhydrinate in the treatment of nausea and vomiting in cancer patients," Journal of the Medical Association of Thailand, vol. 114, no. 7, pp. 121-265, 2011.

[35] G. Ozgoli, M. Goli, and M. Simbar, "Effects of ginger capsules on pregnancy, nausea, and vomiting," The Journal of Alternative and Complementary Medicine, vol. 15, no. 3, pp. 243-246, 2009. 


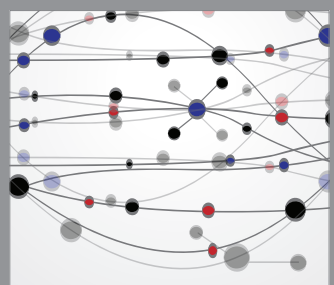

The Scientific World Journal
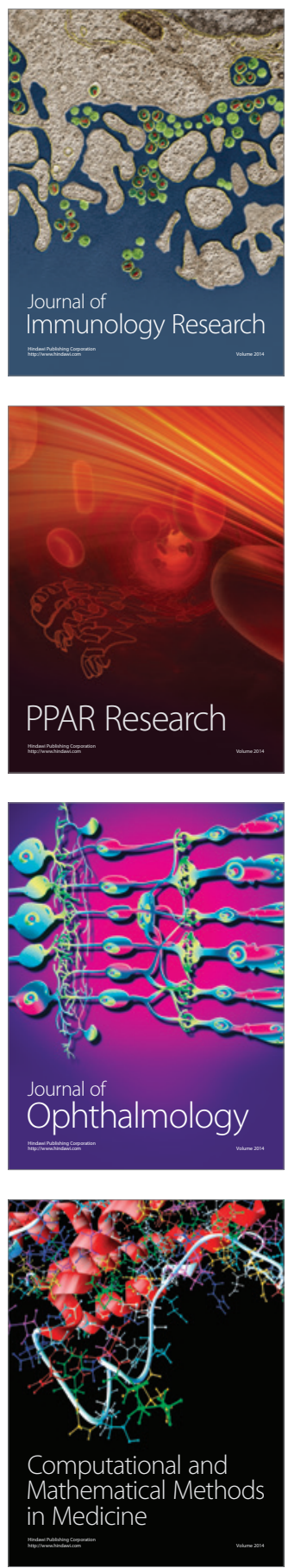

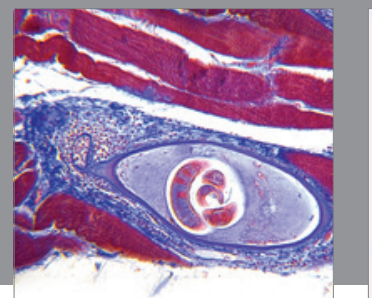

Gastroenterology

Research and Practice
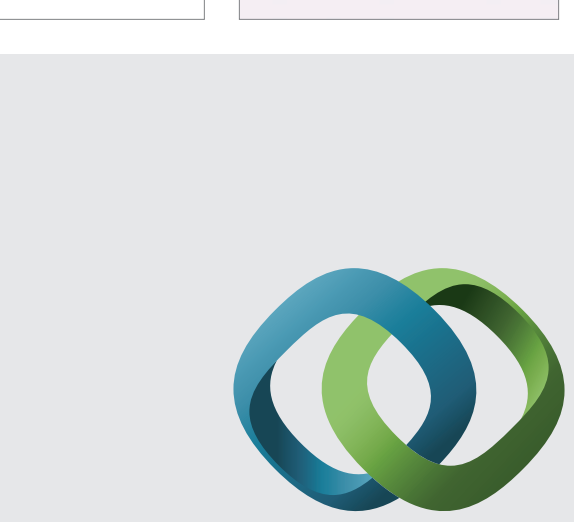

\section{Hindawi}

Submit your manuscripts at

http://www.hindawi.com
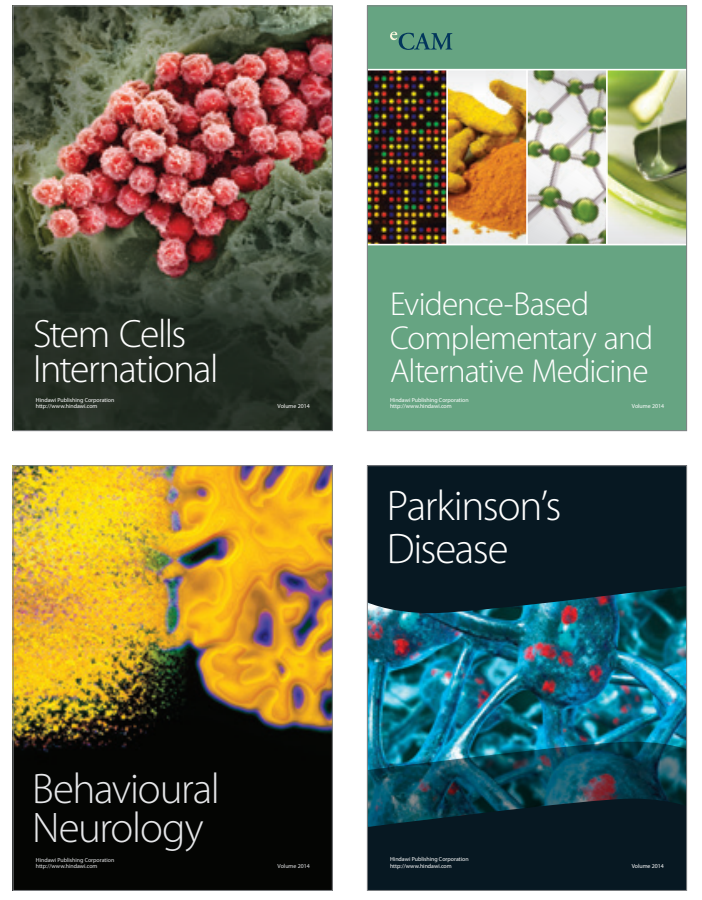
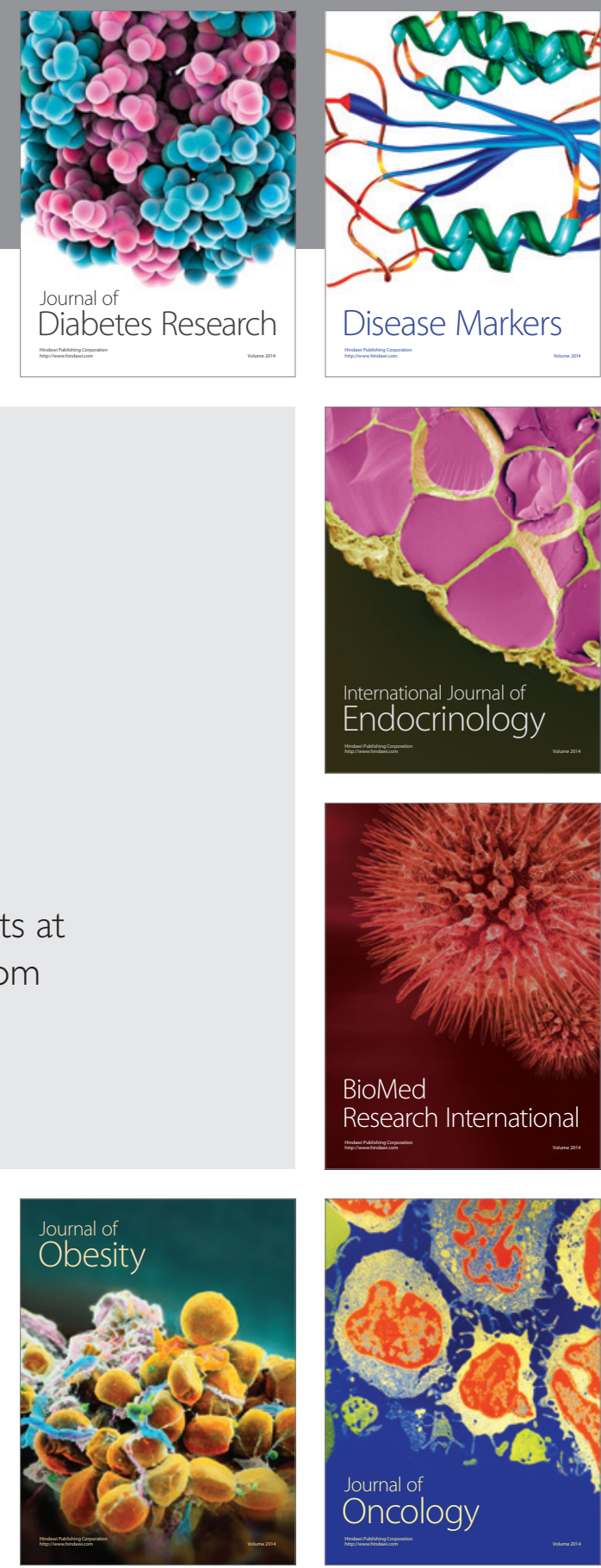

Disease Markers
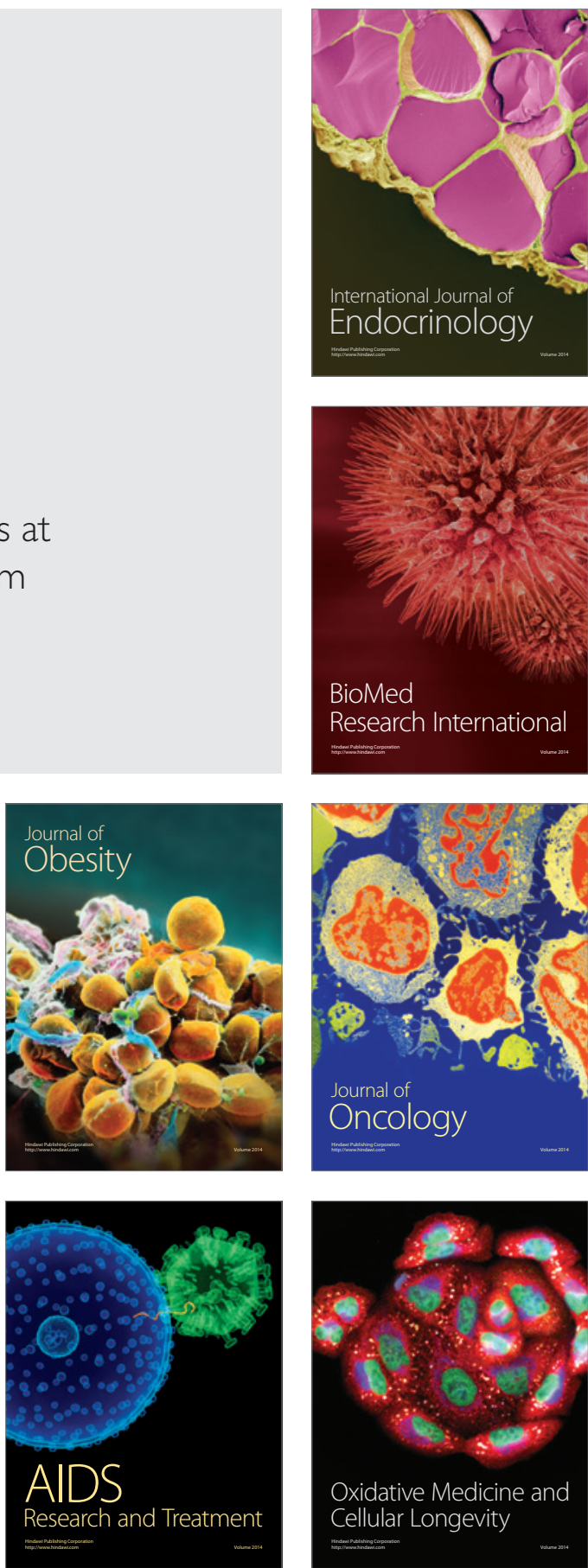